\title{
Assessment on knowledge, attitude, practices and risk of infection towards COVID-19 in Ethiopia: An online cross-sectional survey
}

\author{
Solomon Benor \\ Addis Ababa Science and Technology University \\ Solomon Abera \\ Addis Ababa Science and Technology University \\ Ayele Mandefro \\ Addis Ababa Science and Technology University \\ Rocktotpal Konwarh \\ Addis Ababa Science and Technology University https://orcid.org/0000-0003-4767-4531 \\ Arumuganainar Suresh ( suresh.suresh@aastu.edu.et) \\ Addis Ababa Science and Technology University https://orcid.org/0000-0002-3193-0345
}

\section{Research Article}

Keywords: Attitude, COVID-19, Ethiopia, Knowledge, Practice

Posted Date: November 6th, 2020

DOI: https://doi.org/10.21203/rs.3.rs-103859/v1

License: (9) (i) This work is licensed under a Creative Commons Attribution 4.0 International License. Read Full License 


\section{Abstract}

COVID-19 has ushered in a catastrophe of an unprecedented scale across all parts of the world. Confirmed cases and death toll are constantly on an upward trend. Various measures to control the disease have been adopted globally including in Ethiopia. However, people's adherence to such control measures is affected by their knowledge, attitudes and practices (KAP) during the pandemic. This cross-sectional online survey was therefore, conducted to appraise the KAP vis-a-vis COVID-19 containment strategy during May 13-25, 2020. The online survey questionnaire consisted of demographic characteristics and interrogations, pertaining to knowledge (15 items), attitude (10 items) and practices (7 items), framed in accordance to previous studies. A total of 1,484 respondents completed the survey. The overall correct response rating and average score of the knowledge were $74.7 \%$ and $11.2 \pm 2.2$ respectively. Maximum respondents (63\%) could be bracketed together with a moderate level on knowledge, attitudes while only $43 \%$ had moderate level of practice, with significant difference across demographic variables. Despite the moderate level, the practices were not creditable as the registered values evinced that 1 out of 5 never wore nose mask, washed hands or maintained social distance. In a similar vein, $17.6 \%$, and $43.2 \%$ of the respondents were in high and in medium risk of infection, respectively. Results of our study recommended the importance and need of health education programs aimed at improving KAP, especially the practices in the milieu of COVID-19.

\section{Introduction}

COVID-19, declared as 'Public Health Emergency of International Concern' (PHEIC) on January 30, 2020 [1] and consequently, a pandemic on March 11, 2020 by World Health Organization [2] has set the entire globe out of gear. This topsy-turvy of an unparalleled scale, caused by the novel betacoronavirus, SARSCoV-2 does not need any elaboration. Discernible by major infection of the lower airways and access via binding to angiotensin-converting enzyme 2 (ACE2) on alveolar epithelial cells, the pathogenesis is associated with 'cytokine storm' or 'cytokine cascade' - the proposed mechanism of organ damage [3-5]. With an incubation period of 2-14 days for the virus, the clinical symptoms of the disease include fever, dry cough, fatigue, and shortness of breath while severe stage is characterized by acute respiratory distress syndrome and pneumonia [6, 7]. Albeit the current SARS-CoV-2 shares 79\% of its (RNA) genome with SARS-CoV, the former appears to be much more transmissible with human to human contact being the major transmission route. Asymptomatic transmission of the virus has been marked as the Achilles' heel in the context of the current control strategies of the pandemic [8]. As of today (29th July, 2020), 16,741,049 confirmed cases in 188 countries and a death toll of 660,428 worldwide (the number being an upward trend daily) [9]. Albeit, the average mortality rate of 4\% is comparatively lower than that of SARS (9.5\%), MERS (34.4\%), H7N9 (39.0\%), Ebola (25-95\%) [10, 11], howbeit, COVID-19 has projected itself as a microscopic holocaust over the last few months [12].

Needless to say, researchers worldwide are toiling to develop befitting strategies to detect and target the virus [12, 13]. However, to our dismay, there is neither a potent vaccine nor recommended medications to treat the disease till date. Pertinently, SARS-CoV-2 has spelled devastation in various developed countries even though they have been acknowledged for their well-structured health service time and again. Its spread in Africa may be more catastrophic in the context of lack of adequate health systems. Various measures have been adopted globally to control and contain the disease, including enforcement of 'lockdown' in various countries. Due to its global threat and alarming predictions, online courses on awareness and strategic preparedness and response plan (SPRP) around the world were initiated to protect the states with weaker health infrastructures [14]. In this backdrop, as well perceived, strong infection control practices are the key to minimize the spread of the virus in both health care settings and the community [14]. In the African context, Ethiopia, a densely populated nation without a robust healthcare infrastructure, is leaving no stones unturned to combat the viral assault. However, certain degree of panic resides in public due to the unavailability of basic protection measures. 15,200 confirmed cases and 239 deaths as on $29^{\text {th }}$ July 2020 have been registered since the confirmation of the $1^{\text {st }}$ case on $13^{\text {th }}$ March 2020 [9], however, this number may reflect a shortage of tests [15]. In this regard, besides declaration of a state of emergency (SOE) for 5 months (April-August, 2020) and ensuring timely execution of the viral detection test, Ethiopian government is beavering to combat the debacle through various suggestive measures. Some of these include maintenance of social distancing, wearing of nose masks, frequent washing of hands using soap/appropriate sanitizer and avoidance of crowded places, shutting down of schools and higher education, and door to door temperature check to stop community spreading.

Pertinently, people's adherence to and success of such control measures is affected by their knowledge, attitude and practices (KAP) towards epidemic diseases [16]. In support of this, studies conducted during SARS [17] and MERS outbreak [18] in 2003 and 2012 respectively, suggested that KAP towards infectious diseases are associated with the level of panic-emotion and dread among the population, which can further obfuscate attempts to prevent the spread of the disease. Public knowledge and attitudes towards the disease is germane to adoption of appropriate practices, which are expected to eventually contain the disease. To facilitate outbreak management of COVID-19, many countries including various African nations (Egypt, Kenya, Sudan, Nigeria, Cameroon, Ghana and Tanzania [19-25]) piloted KAP surveys for their citizens, health workers as well as policy makers. The Ministry of Science and Higher Education (MoSHE), a Ministry mandated to coordinate science at national level and oversee all public and private higher education institutions in the country conducted an online survey and collected data on fourteen research categories that also includes knowledge, attitude and practices [26]. A small number of undergraduate students in Debre Berhan University [27], nurses in Aksum St. Marry General Hospital and Aksum Comprehensive Specialized Hospital [28] and hospital visitors in Jimma University Medical center [29] had been surveyed (offline) for KAP towards COVID-19. However, the imperative is to understand KAP among the Ethiopians towards COVID-19 from a national perspective. In this milieu, this online survey was steered to delve into Ethiopians' KAP and risk assessment amidst the COVID-19 outbreak. We anticipate that the survey would be instrumental in identifying key variables to generate informed decision in the control of COVID-19 by the relevant authorities.

\section{Materials And Methods}

\section{Survey plan and participants}


Data-collection for this cross-sectional survey among Ethiopian citizens commenced on May 13, 2020 and concluded on May 25, 2020. During this period the COVID-19 cases were documented between 350 and 500 with only 5 deaths. The citizens were instructed to maintain social distance, wear mask, wash hands, and avoid large gathering and shutdown educational institutions, amongst some of the preventive measures, put forth by the Ethiopian government. It was not feasible to conduct an off-line survey during the state of emergency (SoE), therefore, data for this study was collected using an online survey tool of Google form. Relying on authors' network, a one-page poster, highlighting the survey details was circulated via various social media platforms such as Telegram, Facebook, WhatsApp and group e-mail accounts. The poster contained an introductory description, objectives of the survey, other requirements for the respondents including the voluntary participation, declaration of anonymity and confidentiality, link and QR code, as well as the invigilators' details (S1 Fig). Ethiopian citizens of 18 years and above, and with clear understanding of the content of the poster participated in the study.

\section{Ethical considerations}

All procedures performed in this study, involving human participants, complied with the institutional and/or national research committee ethical standards, and the study was designed and conducted in accordance with the ethical principles established by th "Committee on Publication Ethics (COPE)" guidelines to handle publication ethics. Confidentiality of the participants' information was ensured throughout the study. The online pages for the self-administered questionnaire could be accessed by the participants for attempting and completion, subjected to indication (through a click on 'Yes' button) of consent for voluntary participation.

\section{Questionnaires and score}

A survey questionnaire was designed based on recent study on COVID-19 in Ethiopia [26] and other countries. The questionnaire consisted of four parts: demographics of participants, knowledge, attitudes, and practices of COVID-19. Demographic variables included gender, age, marital status, education status, occupation and geographical location of the respondents (Table 1, Fig 1). The authors had developed a set of 15 questions to assess the respondents' knowledge on COVID-19 (Table 2, S1 Table). These were either multiple-choice questions or true/false queries (including the option as 'I don't know'). A correct answer was allotted 1 point while no point was awarded for an incorrect or 'I don't know' response. The knowledge-score ranged from 0 to 15 ; a cut off level of <7 was set as 'poor', 8-12 for 'moderate', and 13-15 was ranked as a 'good' knowledge-score. A total of 10 questions on attitude towards COVID-19 (Table 3) were supposed to be rated in the 5- point Likert's scale: strongly disagree (1), disagree (2), neutral (3), agree (4) and strongly agree (5) for positive attitude questions. For the negative-attitude questions, respondents were allotted the lowest score of 1 in case their response was 'strongly agree', with scores increasing to 5 with responses marked as 'strongly disagree'. Scores of <25, 26-40 and $>41$ corresponded to 'poor', 'moderate' and 'good' attitude respectively. A total of 7 questions, pertaining to practices of the respondents (Table 4) were to be rated on the 3-point Likert scale format, ranging from never (1), sometimes (2), and always (3). In the case of negative practice question, the scores were reversed. Scores of $<10,11-18$ and $>19$ indicated 'poor', 'moderate' and 'good' level of practices of the respondents towards the outbreak of COVID-19. The assessment on 'risk of infection' was scrutinized based on the practice skills.

\section{Statistical analysis}

The data collected from the survey were collated and the incomplete and repeated responses were excluded. The first complete responses were counted as accurate. The descriptive statistics and one-way analysis of variance (ANOVA), or Chi-square test as appropriate were performed using Microsoft Excel to assess the differences between groups for selected demographic variables and their KAP toward COVID-19. Regression tests were applied to find any correlation between knowledge, attitude and practice scores. The statistical significance level was set at $p<0.05$.

\section{Results}

\section{Demographic characteristics}

Albeit, a total of 1,991 participants attempted the survey questionnaire, howbeit, 177 and 330 responses were incomplete and repeated attempts respectively. The first complete attempted responses were taken into consideration while the repeated attempts and incomplete responses were excluded ( $n=507)$. Thus, the final count consisted of 1,484 responses. Among these, $87 \%$ of the respondents were male while majority of the respondents (54\%) were within the age range of 18-29 years (Table 1). The proportion of married to non-married response was almost similar. The majority of respondents were postgraduates or those enrolled in PG program (58.4\%). The education-status of 54 participants was $<12^{\text {th }}$ grade. In terms of occupation, majority of respondents (62. $6 \%$ ), were government employees, followed by students (12.9\%), privately employed (11.6\%) and health care workers (11.1\%). The participants hailed from all the states of the country with maximum representation from Oromia (31.1\%), followed by SNNAP (17.3\%), Amhara (17.2\%), and Addis Ababa (14.6\%) whereas the least (a single respondent) was from Gambela (Fig 1). Other demographic characteristics are shown in Table 1.

Table 1. Demographic characteristics of participants $(n=1,484)$ 


\begin{tabular}{|c|c|c|c|}
\hline \multicolumn{2}{|c|}{ Demographic characteristics } & $n$ & $\%$ \\
\hline \multirow[t]{2}{*}{ Gender } & Male & 1291 & 87.0 \\
\hline & Female & 193 & 13.0 \\
\hline \multirow[t]{3}{*}{ Age } & $18-29$ & 804 & 54.2 \\
\hline & $30-49$ & 652 & 43.9 \\
\hline & $50-69$ & 28 & 1.9 \\
\hline \multirow[t]{3}{*}{ Marital status } & Married & 740 & 49.9 \\
\hline & Unmarried & 743 & 50.1 \\
\hline & Others (Divorced) & 1 & 0.1 \\
\hline \multirow[t]{4}{*}{ Education status } & $<12^{\text {th }}$ grade & 54 & 3.6 \\
\hline & UG (holding or pursuing) & 411 & 27.7 \\
\hline & PG (holding or pursuing) & 867 & 58.4 \\
\hline & Ph.D. (holding or pursuing) & 152 & 10.2 \\
\hline \multirow[t]{5}{*}{ Occupation } & Student & 192 & 12.9 \\
\hline & Private job & 172 & 11.6 \\
\hline & Government Job & 929 & 62.6 \\
\hline & Health workers ${ }^{1}$ & 164 & 11.1 \\
\hline & Others (self, unemployed) & 27 & 1.8 \\
\hline${ }^{1}$ nurse, physicia & harmacist, lab assistant. & & \\
\hline
\end{tabular}

\section{Assessment of knowledge}

A total of 15 questions were used to assess the participants' knowledge/awareness on COVID-19. The documented average knowledge score was $11.2 \pm 2.2$ (range 2-15). The overall correct answer rating for the knowledge-section of the questionnaire was 74.7\% (11.2*100/15). As shown in Table 2, more than half the respondents selected the correct choices for expansion of the acronym 'COVID-19' as Coronavirus disease 2019 (52.6\%), the place of its origin (97.4\%), its spreading routes (84.9\%), causal virus (57.7\%), main symptoms (79.2\%) and current level of vaccine development (93.7\%). Around half of the participants (48.2\%) correctly answered the minimal prescribed norms for social distancing as ' 6 feet' while 3 out of 10 (28.2\%) ruled out the possibility of spreading the disease by pet animals. The prescribed quarantine period of 14 days for suspected people was correctly documented by all. Pertinently, higher knowledge scores were registered for health care workers (12.6 \pm 1.9 ), people residing in Harari state (12.5 \pm 2.4 ), those in the age-group of $30-49$ (11.6 \pm 2.0 ), and respondents, holding or pursuing Ph.D. degree (11.5 \pm 2.0 ). The least knowledge score was registered at $8.9 \pm 3.0$ and $9.6 \pm 3.2$ for the respondents from Somali state and participants with education only up to school level respectively. Knowledge scores significantly $(p<0.001)$ differed across age-groups, education levels, occupation and residence-state of the participants and marital status $(p<0.05)$ while no significant difference was observed with respect to gender of the participants (Table 5). On a general note, the majority of the participants had a moderate knowledge level towards different items as inquired in the knowledge-section of the questionnaire (Table 6). Age, education, occupation, and geographical location of the participants exerted significant influence $(p<0.001)$ on the knowledge level. There was no significant difference $(p>0.05)$ in the knowledge level with respect to gender and marital status.

Table 2. Knowledge and awareness of Ethiopians towards COVID-19 $(n=1,484)$ 


\begin{tabular}{|c|c|c|c|}
\hline \multicolumn{2}{|c|}{ Knowledge questionnaires } & \multicolumn{2}{|c|}{ Frequency (\%) } \\
\hline & & \multirow{2}{*}{$\begin{array}{l}\text { Correct } \\
781(52.6)\end{array}$} & \multirow{2}{*}{$\begin{array}{l}\text { Incorrect } \\
703 \text { (47.4) }\end{array}$} \\
\hline K1 & Expansion of COVID-19. & & \\
\hline$K 2$ & Which city reported the first case of COVID-19? & $1446(97.4)$ & $38(2.6)$ \\
\hline K3 & Which virus causes COVID-19? & $856(57.7)$ & $628(42.3)$ \\
\hline K4 & How COVID-19 spreads mainly? & $1260(84.9)$ & $224(15.1)$ \\
\hline K5 & Pet animals can spread COVID-19. & $418(28.2)$ & $1066(71.8)$ \\
\hline K6 & Three main symptoms of COVID-19. & $1175(79.2)$ & $309(20.8)$ \\
\hline K7 & Suspected people isolated and observed in quarantine for how many days? & 1473 (99.3) & $11(0.7)$ \\
\hline K8 & What is the Mortality rate (death rate) on COVID-19 worldwide? & $1097(73.9)$ & $387(26.1)$ \\
\hline K9 & Which is the best preventive measure for COVID-19? & $1221(82.3)$ & $263(17.7)$ \\
\hline K10 & How many feet are appropriate for maintaining social distance to prevent COVID-19 spread? & $716(48.3)$ & $768(51.7)$ \\
\hline K11 & How many seconds are suggested to wash your hands with soap to prevent COVID-19 spread? & $1411(95.1)$ & $73(4.9)$ \\
\hline K12 & If you have only one nose mask, whom you give the mask to wear? & $825(55.6)$ & $659(44.4)$ \\
\hline K13 & Effective treatment is available for COVID-19. & 1231 (83.0) & $253(17.0)$ \\
\hline K14 & We cannot prevent COVID-19 spread & 1334 (89.9) & $150(10.1)$ \\
\hline K15 & Vaccines are not available for COVID-19 at the moment. & $1390(93.7)$ & $94(6.3)$ \\
\hline
\end{tabular}

\section{Assessment of attitudes}

The responses obtained against the items, pertaining to 'attitude of the respondents' towards COVID-19 are depicted in Table 3. About 94.1\% ( $n=1,397$ ) (of which $82.5 \%$ marked 'strongly agreed') were of the view that COVID-19 is posing a serious health issue in the society. A majority of participants (74.2\%) was confident that COVID-19 would be successfully addressed and combatted by the Ethiopian government through its various proactive measures. Howbeit, a considerable fraction of the respondents (11.3\%) were not upbeat about the same. Almost 63 \% participants agreed that the people in Ethiopia are in a state of panic with respect to COVID-19 and apprehensive of contracting the infection. Most (79.7\%) of the participants thought that travelling is the prime reason for acquiring COVID-19 infection. On the other hand, $68.3 \%$ had projected that their daily life was negatively affected due to COVID-19. Approximately, 65.5\% of the participants supported the permission of patients, recovered from COVID-19 infection into the society, while $18.1 \%$ was against it. Nearly $90 \%$ participants vouched for self-isolation in case they would exhibit symptoms of COVID-19. As against $37 \%$ respondents being neutral, $38.8 \%$ and $32 \%$ participants disagreed that COVID-19 virus is synthetic and a bioweapon. Attitude significantly $(p<0.001)$ differed among participants for all questions except for query pertaining to COVID-19 causing virus being a bioweapon or not. There was no significant difference at $p<0.05$ for attitude score with respect to gender of the participants. For the parameters of age and education, attitude score increased with increase in age and education level, for example maximum attitude score was observed for participants in the age group of 50-69 (3.95 \pm 0.48$)$ and postgraduates (3.90 \pm 0.47$)$ while minimum was documented for those in the age group of 18-29 (3.82 \pm 0.51$)$ and educated up to school level (3.53 \pm 0.53$)$ respectively. Health care workers recorded higher attitude score $(4.00 \pm 0.54)$ than any others in the occupation category and the least was documented by those engaged in private job (3.73 \pm 0.49$)$. The highest attitude score was recorded for the participants from the state of Benishangul-Gumaz (4.06 \pm 0.54 ) followed by SNNAP (3.92 \pm 0.42$)$. The attitude score was significantly associated with age group ( $p<0.05)$, marital status, education status, occupation and state of the respondents at $p<0.001$ (Table 5$)$. Classifying the attitude level as poor, moderate and good towards COVID-19, generally speaking, the majority of the participants had a moderate attitude towards different queries, enlisted in the questionnaire (Table 6). Marital status ( $p$-value $=0.030$ ), education status ( $p$-value $=0.026)$, occupation $(p$-value $=0.004)$, and geographical area ( $p$-value $=0.007$ ) of the participants seemed to exert significant influence on their attitude level for the observations, recorded during the survey period. There was no significant difference $(p>0.05)$ in the attitude level with respect to gender and age. Regression tests revealed that there was a statistically significant positive linear correlation between knowledge and attitudes $(r=0.162, p<0.001)$ (Table 7).

Table 3. Attitudes of Ethiopians towards COVID-19 $(n=1,484)$ 


\begin{tabular}{|c|c|c|c|c|c|c|c|c|c|c|c|c|c|c|}
\hline \multicolumn{2}{|c|}{ Attitude questionnaires } & \multicolumn{2}{|c|}{$\begin{array}{l}\text { Strongly } \\
\text { disagree (1) }\end{array}$} & \multicolumn{2}{|c|}{$\begin{array}{l}\text { Disagree } \\
\text { (2) }\end{array}$} & \multicolumn{2}{|c|}{ Neutral (3) } & \multicolumn{2}{|c|}{ Agree (4) } & \multicolumn{2}{|c|}{$\begin{array}{l}\text { Strongly } \\
\text { agree (5) }\end{array}$} & \multirow[t]{2}{*}{$\begin{array}{l}\text { Average } \\
\text { score }\end{array}$} & \multirow[t]{2}{*}{$S D$} & \multirow[t]{2}{*}{$P$-value } \\
\hline & & $n$ & $\%$ & $n$ & $\%$ & $n$ & $\%$ & $n$ & $\%$ & $n$ & $\%$ & & & \\
\hline$A 1$ & $\begin{array}{l}\text { You think COVID-19 is a serious } \\
\text { public health threat. }\end{array}$ & 34 & 2.3 & 19 & 1.3 & 34 & 2.3 & 172 & 11.6 & 1225 & 82.5 & 4.71 & 0.60 & $<0.001^{* * *}$ \\
\hline$A 2$ & $\begin{array}{l}\text { People are panicked in Ethiopia } \\
\text { about COVID-19, including my self }\end{array}$ & 75 & 5.1 & 157 & 10.6 & 309 & 20.8 & 570 & 38.4 & 373 & 25.1 & 3.68 & 1.24 & $<0.001^{* * *}$ \\
\hline A3 & $\begin{array}{l}\text { The Ethiopian government is doing a } \\
\text { great effort in controlling the spread } \\
\text { of COVID-19. }\end{array}$ & 69 & 4.6 & 100 & 6.7 & 214 & 14.4 & 553 & 37.3 & 548 & 36.9 & 3.95 & 1.20 & $<0.001^{* * *}$ \\
\hline A4 & $\begin{array}{l}\text { Traveling is a main reason for } \\
\text { getting COVID-19. }\end{array}$ & 54 & 3.6 & 104 & 7.0 & 144 & 9.7 & 507 & 34.2 & 675 & 45.5 & 4.11 & 1.15 & $<0.001^{* * *}$ \\
\hline$A 5$ & $\begin{array}{l}\text { Patients cured of COVID-19 can be } \\
\text { allowed to society. }\end{array}$ & 164 & 11.1 & 104 & 7.0 & 243 & 16.4 & 487 & 32.8 & 486 & 32.7 & 3.69 & 1.67 & $<0.001 * * *$ \\
\hline$A 6$ & $\begin{array}{l}\text { I am worried about getting the } \\
\text { COVID-19. }\end{array}$ & 107 & 7.2 & 156 & 10.5 & 275 & 18.5 & 489 & 33.0 & 457 & 30.8 & 3.70 & 1.47 & $<0.001 * * *$ \\
\hline A7 & $\begin{array}{l}\text { My daily life is spoiled due to COVID- } \\
19 \text { outbreak. }\end{array}$ & 84 & 5.7 & 143 & 9.6 & 244 & 16.4 & 489 & 33.0 & 524 & 35.3 & 3.83 & 1.38 & $<0.001 * * *$ \\
\hline A8 & $\begin{array}{l}\text { If I have symptoms of COVID-19, I } \\
\text { isolate myself. }\end{array}$ & 73 & 4.9 & 27 & 1.8 & 36 & 2.4 & 166 & 11.2 & 1182 & 79.6 & 4.59 & 0.99 & $<0.001^{* * *}$ \\
\hline$A 9$ & $\begin{array}{l}\text { This COVID-19 is caused by a } \\
\text { synthetic virus (man-made). }\end{array}$ & 365 & 24.6 & 210 & 14.2 & 574 & 38.7 & 160 & 10.8 & 175 & 11.8 & 2.71 & 1.62 & $<0.001 * * *$ \\
\hline$A 10$ & $\begin{array}{l}\text { This COVID-19 causing virus is a } \\
\text { bioweapon. }\end{array}$ & 284 & 19.1 & 192 & 12.9 & 546 & 36.8 & 230 & 15.5 & 232 & 15.6 & 2.96 & 1.67 & 0.647 \\
\hline
\end{tabular}

\section{Assessment of practices}

Table 4 represents the responses recorded for practice items of the questionnaire towards COVID-19. When enquired about wearing nose mask while going out in this COVID-19 outbreak, surprisingly, 1 out of 5 participants reported that they 'never' wore a nose mask, $43 \%$ marked 'sometimes' while only $36.2 \%$ resorted to a nose mask every time. Notably, $67.6 \%$ and $51.6 \%$ participants remarked positively about washing theirs hand after going out and carrying a sanitizer 'always' in contrast to 1 out of 5 participants who neither washed their hands after going out, nor carried a sanitizer. More than half of the participants ( $n=777$ ) asserted the maintenance of social distancing during the survey period. Surprisingly, $19.1 \%$ of participants remarked that they never engaged in using a nose mask, washing hands or maintaining social distance during the COVID-19 outbreak. Around $56.3 \%$ of the participants marked 'always' with respect to avoidance of crowded place like worship place, bus and train stations, banks and malls, while 1 out of 4 and 1 out of 5 chose 'sometimes' and 'never' respectively in the online portal. Four out of ten people supported lockdown if imposed in the country to control COVID-19 spread as against $23 \%$ who voiced against such strategy. Almost 66 \% respondents specified that they did not favor the Ethiopian style of greeting (involving hand shake, followed by shoulderhit for man and cheek- touch for woman) during the COVID-19 outbreak, still a considerable portion of the participants was found to second it: $8.4 \%$ 'sometimes' and 25.1 \% 'always'! On demarcating the practices towards COVID-19 as poor, moderate and good, generally speaking, the majority of the participants exhibited moderate practice level in the context of various items, inquired in the questionnaire (Table 6). Age, education status, and geographical location of the participants appeared to significantly impact the practice level while no significant difference $(p>0.05)$ in the practices were recorded for the variables of gender, marital status and occupation. Regression tests revealed that there was a statistically significant) positive linear correlation between attitudes and practices $(r=0.199, p<0.001$, while no significance correlation between knowledge and practice (Table 7).

\section{Assessment of Risk of infection}

Risk of infection was analyzed among all the respondents based on the seven practice-questions (Table 4). Accordingly, 241 (16.24\%) were placed under high risk category, 668 (45\%) in medium risk category, and 575 (38.75\%) in low risk category (Table 6). High risk category people were those who remarked that they never wore mask or engaged in washing hands, maintaining social distance, avoiding crowded places, and preferred hand shake for greeting. By the same token, medium risk category responders adhered to the recommended practices only at times, while people in the low risk category stringently followed the advocated practices, besides avoiding the bodily contact (like hand-shake) for greeting. Relatively, females (20.2\%) were at higher risk than males (15.6 \%). Similarly, greater fraction of low aged respondents (21.1\% for 18-29 age), unmarried (17.9\%) and those with lower education status (33.3\% for school education) were placed in high risk category in comparison to their middle aged (10.4\% for 30-49 age), married (14.6\%) and higher educated (14 \% for PG degree) counterparts. In a similar vein, participants from Somali (32.6\%) and Afar region (28\%) outnumbered their counterparts from other regions in the high risk category (Fig 2). Surprisingly, even healthcare workers (18.3\%) appeared to be in higher risk in contrast to government job employees (14.9\%) and students (14.6\%). 
Table 4. Practices of Ethiopians towards COVID-19 $(n=1,484)$

\begin{tabular}{|c|c|c|c|c|c|c|c|c|c|c|}
\hline \multicolumn{2}{|c|}{ Practice questionnaires } & \multicolumn{2}{|c|}{ Never (1) } & \multicolumn{2}{|c|}{$\begin{array}{l}\text { Sometimes } \\
\text { (2) }\end{array}$} & \multicolumn{2}{|c|}{ Always (3) } & \multirow[t]{2}{*}{$\begin{array}{l}\text { Average } \\
\text { score }\end{array}$} & \multirow[t]{2}{*}{$S D$} & \multirow[t]{2}{*}{$P$-value } \\
\hline & & $n$ & $\%$ & $n$ & $\%$ & $n$ & $\%$ & & & \\
\hline P1 & $\begin{array}{l}\text { Do you wear a nose mask when you go out during the COVID-19 } \\
\text { outbreak? }\end{array}$ & 307 & 20.7 & 640 & 43.1 & 537 & 36.2 & 2.15 & 0.54 & $<0.001^{* * *}$ \\
\hline$P 2$ & Do you carry sanitizer during the COVID-19 outbreak? & 322 & 21.7 & 396 & 26.7 & 766 & 51.6 & 2.30 & 0.64 & $<0.001 * * *$ \\
\hline P3 & Do you maintain social distance during the COVID-19 outbreak? & 282 & 19.0 & 425 & 28.6 & 777 & 52.4 & 2.33 & 0.60 & $<0.001 * * *$ \\
\hline P4 & $\begin{array}{l}\text { Do you prefer to wash your hands after going out during the COVID- } \\
19 \text { outbreak? }\end{array}$ & 332 & 22.4 & 149 & 10.0 & 1003 & 67.6 & 2.45 & 0.70 & $<0.001^{* * *}$ \\
\hline P5 & $\begin{array}{l}\text { Are you avoiding crowded places (Worship places, bus, and train } \\
\text { stations, mall, bank, etc.) these days? }\end{array}$ & 284 & 19.1 & 365 & 24.6 & 835 & 56.3 & 2.37 & 0.62 & $<0.001^{* * *}$ \\
\hline P6 & Do you support if lockdown imposed in Ethiopia to control COVID-19? & 342 & 23.0 & 532 & 35.8 & 610 & 41.1 & 2.18 & 0.61 & $<0.001^{* * *}$ \\
\hline$P 7$ & $\begin{array}{l}\text { In general, Ethiopians greets each other by handshake followed by } \\
\text { shoulder hit for man, cheeks touch for women, do you prefer this way } \\
\text { of greetings in this COVID-19 outbreak? }\end{array}$ & 979 & 66.0 & 125 & 8.4 & 380 & 25.6 & 1.60 & 0.75 & $<0.001^{* * *}$ \\
\hline \multicolumn{11}{|c|}{$* * *$ Statistically significant at $P<0.001$ (chi-square analysis) } \\
\hline
\end{tabular}

Table 5. Distribution of KAP scores among demographic variables of Ethiopians towards COVID-19. 


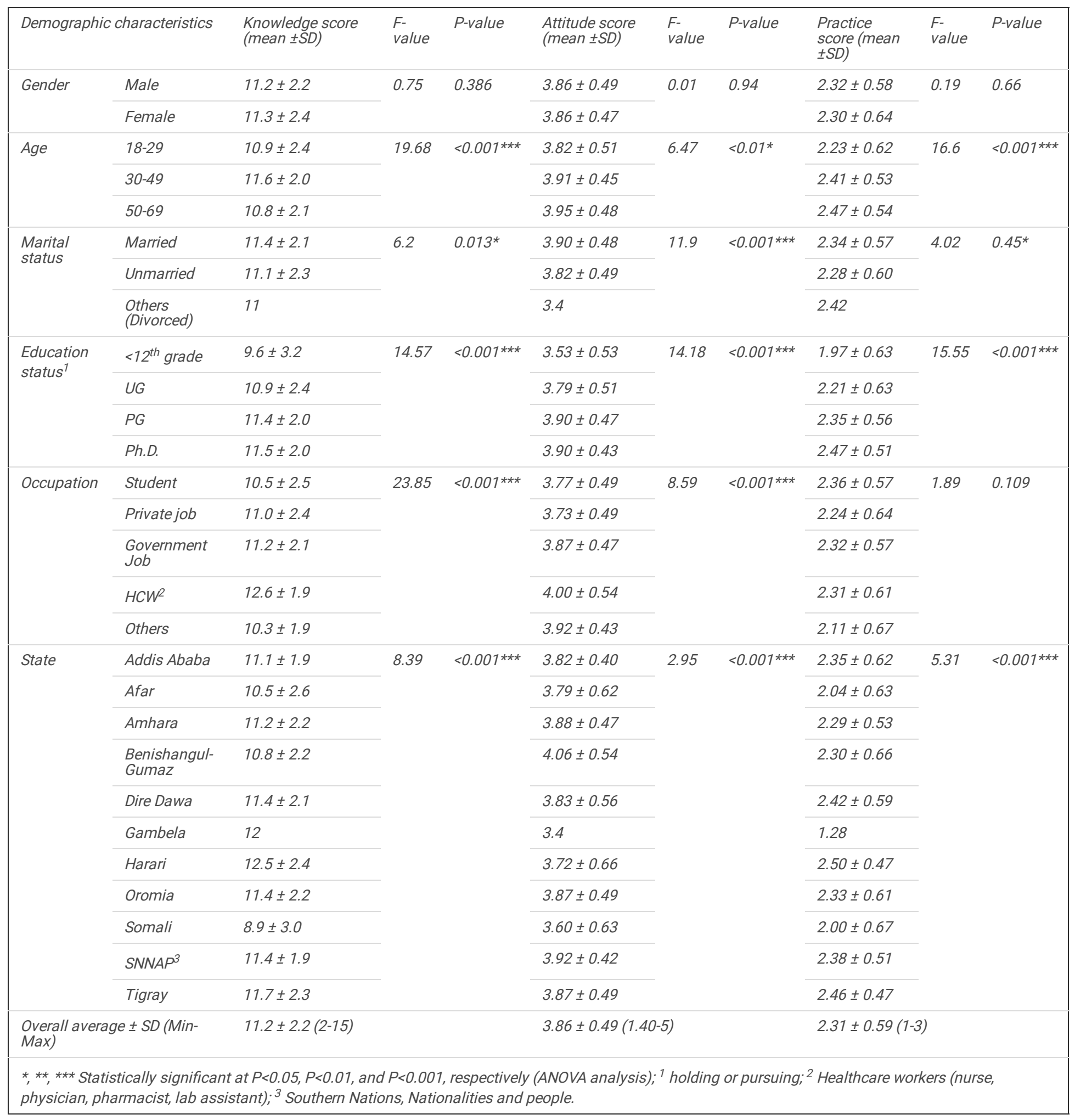

Table 6. Comparisons of demographic characteristics by knowledge, attitudes, and practices skills of Ethiopians towards COVID-19 ( $n=1,484)$ 


\begin{tabular}{|c|c|c|c|c|c|c|c|c|c|c|c|c|c|}
\hline \multicolumn{2}{|c|}{$\begin{array}{l}\text { Demographic } \\
\text { characteristics }\end{array}$} & \multicolumn{3}{|c|}{ Knowledge } & \multirow{3}{*}{$\begin{array}{l}X^{2} \\
\text { (P-value) }\end{array}$} & \multicolumn{3}{|c|}{ Attitude } & \multirow{3}{*}{$\begin{array}{l}X^{2} \\
(P- \\
\text { value })\end{array}$} & \multicolumn{3}{|c|}{ Practice } & \multirow{3}{*}{$\begin{array}{l}X^{2} \\
(P- \\
\text { value })\end{array}$} \\
\hline & & \multirow{2}{*}{$\begin{array}{l}\text { Poor } \\
n \\
(\%)\end{array}$} & \multirow{2}{*}{$\begin{array}{l}\text { Moderate } \\
n(\%)\end{array}$} & \multirow{2}{*}{$\begin{array}{l}\text { Good } \\
n(\%)\end{array}$} & & \multirow{2}{*}{$\begin{array}{l}\text { Poor } \\
n \\
(\%)\end{array}$} & \multirow{2}{*}{$\begin{array}{l}\text { Moderate } \\
n(\%)\end{array}$} & \multirow{2}{*}{$\begin{array}{l}\text { Good } \\
n(\%)\end{array}$} & & \multirow{2}{*}{$\begin{array}{l}\text { Poor } \\
n(\%)\end{array}$} & \multirow{2}{*}{$\begin{array}{l}\text { Moderate } \\
n(\%)\end{array}$} & \multirow{2}{*}{$\begin{array}{l}\text { Good } \\
n(\%)\end{array}$} & \\
\hline & & & & & & & & & & & & & \\
\hline \multirow[t]{2}{*}{ Gender } & Male & $\begin{array}{l}74 \\
(5.7)\end{array}$ & $853(66)$ & $\begin{array}{l}364 \\
(28)\end{array}$ & \multirow{2}{*}{$\begin{array}{l}3.12 \\
(0.210)\end{array}$} & $\begin{array}{l}21 \\
(1.6)\end{array}$ & $\begin{array}{l}820 \\
(63.5)\end{array}$ & $\begin{array}{l}450 \\
(34.9)\end{array}$ & \multirow{2}{*}{$\begin{array}{l}1.49 \\
(0.474)\end{array}$} & $\begin{array}{l}202 \\
(15.6)\end{array}$ & $\begin{array}{l}592 \\
(45.9)\end{array}$ & $\begin{array}{l}497 \\
(38.5)\end{array}$ & \multirow[t]{2}{*}{$\begin{array}{l}3.9 \\
(0.144)\end{array}$} \\
\hline & Female & $\begin{array}{l}13 \\
(6.7)\end{array}$ & $\begin{array}{l}115 \\
(59.6)\end{array}$ & $\begin{array}{l}65 \\
(34)\end{array}$ & & $\begin{array}{l}1 \\
(0.5)\end{array}$ & $\begin{array}{l}122 \\
(63.2)\end{array}$ & $\begin{array}{l}70 \\
(36.3)\end{array}$ & & $\begin{array}{l}39 \\
(20.2)\end{array}$ & 76 (39.4) & $\begin{array}{l}78 \\
(40.4)\end{array}$ & \\
\hline \multirow[t]{3}{*}{ Age } & $18-29$ & $\begin{array}{l}67 \\
(8.3)\end{array}$ & $\begin{array}{l}529 \\
(65.8)\end{array}$ & $\begin{array}{l}208 \\
(26)\end{array}$ & \multirow{3}{*}{$\begin{array}{l}26.29 \\
(<0.001) * * *\end{array}$} & $\begin{array}{l}13 \\
(1.6)\end{array}$ & $\begin{array}{l}527 \\
(65.5)\end{array}$ & $\begin{array}{l}264 \\
(32.8)\end{array}$ & \multirow{3}{*}{$\begin{array}{l}5.31 \\
(0.257)\end{array}$} & $\begin{array}{l}170 \\
(21.1)\end{array}$ & $\begin{array}{l}348 \\
(43.3)\end{array}$ & $\begin{array}{l}286 \\
(35.6)\end{array}$ & \multirow{3}{*}{$\begin{array}{l}34.78 \\
(<0.001 \\
* * *\end{array}$} \\
\hline & $30-49$ & $\begin{array}{l}18 \\
(2.8)\end{array}$ & $\begin{array}{l}419 \\
(64.3)\end{array}$ & $\begin{array}{l}215 \\
\text { (33) }\end{array}$ & & $\begin{array}{l}8 \\
(1.2)\end{array}$ & $\begin{array}{l}400 \\
(61.3)\end{array}$ & $\begin{array}{l}244 \\
(37.4)\end{array}$ & & $\begin{array}{l}68 \\
(10.4)\end{array}$ & $\begin{array}{l}311 \\
(47.7)\end{array}$ & $\begin{array}{l}273 \\
(41.9)\end{array}$ & \\
\hline & $50-69$ & $\begin{array}{l}2 \\
(7.1)\end{array}$ & 20 (71.4) & $\begin{array}{l}6 \\
(21)\end{array}$ & & $\begin{array}{l}1 \\
(3.6)\end{array}$ & $15(53.6)$ & $\begin{array}{l}12 \\
(42.9)\end{array}$ & & $\begin{array}{l}3 \\
(10.7)\end{array}$ & $9(32.1)$ & $\begin{array}{l}16 \\
(57.1)\end{array}$ & \\
\hline \multirow[t]{2}{*}{$\begin{array}{l}\text { Marital } \\
\text { status }\end{array}$} & Married & $\begin{array}{l}37 \\
(5)\end{array}$ & $\begin{array}{l}478 \\
(64.6)\end{array}$ & $\begin{array}{l}225 \\
(30)\end{array}$ & \multirow{2}{*}{$\begin{array}{l}3.09 \\
(0.213)\end{array}$} & $\begin{array}{l}12 \\
(1.6)\end{array}$ & $\begin{array}{l}445 \\
(60.1)\end{array}$ & $\begin{array}{l}283 \\
(38.2)\end{array}$ & \multirow{2}{*}{$\begin{array}{l}7.01 \\
(0.030)^{*}\end{array}$} & $\begin{array}{l}108 \\
(14.6)\end{array}$ & $\begin{array}{l}337 \\
(45.5)\end{array}$ & $\begin{array}{l}295 \\
(39.9)\end{array}$ & $\begin{array}{l}3.00 \\
(0.223)\end{array}$ \\
\hline & Unmarried & $\begin{array}{l}50 \\
(6.7)\end{array}$ & $\begin{array}{l}489 \\
(65.8)\end{array}$ & $\begin{array}{l}204 \\
(27)\end{array}$ & & $\begin{array}{l}10 \\
(1.3)\end{array}$ & $\begin{array}{l}496 \\
(66.8)\end{array}$ & $\begin{array}{l}237 \\
(31.9)\end{array}$ & & $\begin{array}{l}133 \\
(17.9)\end{array}$ & $\begin{array}{l}328 \\
(44.1)\end{array}$ & $\begin{array}{l}282 \\
(38.0)\end{array}$ & \\
\hline $\begin{array}{l}\text { Education } \\
\text { status }^{1}\end{array}$ & $<12^{\text {th }}$ grade & $\begin{array}{l}14 \\
(26)\end{array}$ & $27(50)$ & $\begin{array}{l}13 \\
(24)\end{array}$ & 60.15 & $\begin{array}{l}2 \\
(3.7)\end{array}$ & 39 (72.2) & $\begin{array}{l}13 \\
(24.1)\end{array}$ & 14.32 & $\begin{array}{l}18 \\
(33.3)\end{array}$ & $24(44.4)$ & $\begin{array}{l}12 \\
(22.2)\end{array}$ & $\begin{array}{l}33.59 \\
(<0.001\end{array}$ \\
\hline & UG & $\begin{array}{l}38 \\
(9.2)\end{array}$ & $267(65)$ & $\begin{array}{l}106 \\
(26)\end{array}$ & & $\begin{array}{l}8 \\
(1.9)\end{array}$ & $\begin{array}{l}278 \\
(67.6)\end{array}$ & $\begin{array}{l}125 \\
(30.4)\end{array}$ & * & $\begin{array}{l}85 \\
(20.7)\end{array}$ & $\begin{array}{l}190 \\
(46.2)\end{array}$ & $\begin{array}{l}136 \\
(33.1)\end{array}$ & $* * *$ \\
\hline & $P G$ & $\begin{array}{l}29 \\
(3.3)\end{array}$ & $\begin{array}{l}573 \\
(66.1)\end{array}$ & $\begin{array}{l}265 \\
(31)\end{array}$ & & $\begin{array}{l}11 \\
(1.3)\end{array}$ & $\begin{array}{l}523 \\
(60.3)\end{array}$ & $\begin{array}{l}333 \\
(38.4)\end{array}$ & & $\begin{array}{l}121 \\
(14.0)\end{array}$ & $\begin{array}{l}392 \\
(45.2)\end{array}$ & $\begin{array}{l}354 \\
(40.8)\end{array}$ & \\
\hline & Ph.D. & $\begin{array}{l}6 \\
(3.9)\end{array}$ & $\begin{array}{l}101 \\
(66.4)\end{array}$ & $\begin{array}{l}45 \\
(30)\end{array}$ & & $\begin{array}{l}1 \\
(0.7)\end{array}$ & $\begin{array}{l}102 \\
(67.1)\end{array}$ & $\begin{array}{l}49 \\
(32.2)\end{array}$ & & $\begin{array}{l}17 \\
(11.2)\end{array}$ & $60(39.5)$ & $\begin{array}{l}75 \\
(49.3)\end{array}$ & \\
\hline Occupation & Student & $\begin{array}{l}23 \\
(12)\end{array}$ & $\begin{array}{l}130 \\
(67.7)\end{array}$ & $\begin{array}{l}39 \\
(20)\end{array}$ & & $\begin{array}{l}2 \\
(1.0)\end{array}$ & $\begin{array}{l}133 \\
(69.3)\end{array}$ & $\begin{array}{l}57 \\
(29.7)\end{array}$ & & $\begin{array}{l}28 \\
(14.6)\end{array}$ & $89(46.4)$ & $\begin{array}{l}75 \\
(39.1)\end{array}$ & $\begin{array}{l}8.76 \\
(0.363)\end{array}$ \\
\hline & Private job & $\begin{array}{l}15 \\
(8.7)\end{array}$ & $\begin{array}{l}107 \\
(62.2)\end{array}$ & $\begin{array}{l}50 \\
(29)\end{array}$ & & $\begin{array}{l}5 \\
(2.9)\end{array}$ & $\begin{array}{l}123 \\
(71.5)\end{array}$ & $\begin{array}{l}44 \\
(25.6)\end{array}$ & & $\begin{array}{l}38 \\
(22.1)\end{array}$ & 70 (40.7) & $\begin{array}{l}64 \\
(37.2)\end{array}$ & \\
\hline & $\begin{array}{l}\text { Government } \\
\text { Job }\end{array}$ & $\begin{array}{l}46 \\
(5)\end{array}$ & $\begin{array}{l}637 \\
(68.6)\end{array}$ & $\begin{array}{l}246 \\
(26)\end{array}$ & & $\begin{array}{l}14 \\
(1.5)\end{array}$ & $\begin{array}{l}584 \\
(62.9)\end{array}$ & $\begin{array}{l}331 \\
(35.6)\end{array}$ & & $\begin{array}{l}138 \\
(14.9)\end{array}$ & $\begin{array}{l}427 \\
(46.0)\end{array}$ & $\begin{array}{l}364 \\
(39.2)\end{array}$ & \\
\hline & $H W^{2}$ & $\begin{array}{l}1 \\
(0.6)\end{array}$ & $73(44.5)$ & $\begin{array}{l}90 \\
(55)\end{array}$ & & $\begin{array}{l}1 \\
(0.6)\end{array}$ & $87(53.0)$ & $\begin{array}{l}76 \\
(46.3)\end{array}$ & & $\begin{array}{l}30 \\
(18.3)\end{array}$ & 70 (42.7) & $\begin{array}{l}64 \\
(39.0)\end{array}$ & \\
\hline & Others & $\begin{array}{l}2 \\
(7.4)\end{array}$ & 21 (77.8) & $\begin{array}{l}4 \\
(15)\end{array}$ & & $\begin{array}{l}0 \\
(0.0)\end{array}$ & $15(55.6)$ & $\begin{array}{l}12 \\
(44.4)\end{array}$ & & $\begin{array}{l}7 \\
(25.9)\end{array}$ & $10(37.0)$ & $\begin{array}{l}10 \\
(37.0)\end{array}$ & \\
\hline State & $\begin{array}{l}\text { Addis } \\
\text { Ababa }\end{array}$ & $\begin{array}{l}5 \\
(2.3)\end{array}$ & $\begin{array}{l}157 \\
(72.4)\end{array}$ & $\begin{array}{l}55 \\
(25)\end{array}$ & 108.78 & $\begin{array}{l}0 \\
(0.0)\end{array}$ & $\begin{array}{l}152 \\
(70.0)\end{array}$ & $\begin{array}{l}65 \\
(30.0)\end{array}$ & 35.83 & $\begin{array}{l}36 \\
(16.6)\end{array}$ & 79 (36.4) & $\begin{array}{l}102 \\
(47.0)\end{array}$ & $\begin{array}{l}67.95 \\
1<0.001\end{array}$ \\
\hline & Afar & $\begin{array}{l}11 \\
(11)\end{array}$ & $67(67)$ & $\begin{array}{l}22 \\
(22)\end{array}$ & & $\begin{array}{l}5 \\
(5.0)\end{array}$ & $62(62.0)$ & $\begin{array}{l}33 \\
(33.0)\end{array}$ & & $\begin{array}{l}28 \\
(28.0)\end{array}$ & 51 (51.0) & $\begin{array}{l}21 \\
(21.0)\end{array}$ & $* * *$ \\
\hline & Amhara & $\begin{array}{l}15 \\
(5.8)\end{array}$ & $\begin{array}{l}170 \\
(65.6)\end{array}$ & $\begin{array}{l}74 \\
(29)\end{array}$ & & $\begin{array}{l}2 \\
(0.8)\end{array}$ & $\begin{array}{l}159 \\
(61.4)\end{array}$ & $\begin{array}{l}98 \\
(37.8)\end{array}$ & & $\begin{array}{l}31 \\
(12.0)\end{array}$ & $\begin{array}{l}145 \\
(56.0)\end{array}$ & $\begin{array}{l}83 \\
(32.0)\end{array}$ & \\
\hline & $B G^{3}$ & $\begin{array}{l}2 \\
(6.9)\end{array}$ & $19(65.5)$ & $\begin{array}{l}8 \\
(28)\end{array}$ & & $\begin{array}{l}1 \\
(3.4)\end{array}$ & $15(51.7)$ & $\begin{array}{l}13 \\
(44.8)\end{array}$ & & $\begin{array}{l}6 \\
(20.7)\end{array}$ & $9(31.0)$ & $\begin{array}{l}14 \\
(48.3)\end{array}$ & \\
\hline & Dire Dawa & $\begin{array}{l}1 \\
(2.4)\end{array}$ & $30(71.4)$ & $\begin{array}{l}11 \\
(26)\end{array}$ & & $\begin{array}{l}3 \\
(7.1)\end{array}$ & $24(57.1)$ & $\begin{array}{l}15 \\
(35.7)\end{array}$ & & $\begin{array}{l}5 \\
(11.9)\end{array}$ & $16(38.1)$ & $\begin{array}{l}21 \\
(50.0)\end{array}$ & \\
\hline & Harari & $\begin{array}{l}1 \\
\text { (8.3) }\end{array}$ & 4 (33.3) & $\begin{array}{l}7 \\
(58)\end{array}$ & & $\begin{array}{l}0 \\
(0.0)\end{array}$ & $8(66.7)$ & $\begin{array}{l}4 \\
\text { (33.3) }\end{array}$ & & $\begin{array}{l}1 \\
\text { (8.3) }\end{array}$ & $5(41.7)$ & $\begin{array}{l}6 \\
(50.0)\end{array}$ & \\
\hline & Oromia & $\begin{array}{l}23 \\
(5)\end{array}$ & $\begin{array}{l}296 \\
(64.1)\end{array}$ & $\begin{array}{l}143 \\
(31)\end{array}$ & & $\begin{array}{l}7 \\
(1.5)\end{array}$ & $\begin{array}{l}293 \\
(63.4)\end{array}$ & $\begin{array}{l}162 \\
(35.1)\end{array}$ & & $\begin{array}{l}82 \\
(17.7)\end{array}$ & $\begin{array}{l}180 \\
(39.0)\end{array}$ & $\begin{array}{l}200 \\
(43.3)\end{array}$ & \\
\hline & Somali & $\begin{array}{l}17 \\
(37)\end{array}$ & $22(47.8)$ & $\begin{array}{l}7 \\
(15)\end{array}$ & & $\begin{array}{l}2 \\
\text { (4.3) }\end{array}$ & 33 (71.7) & $\begin{array}{l}11 \\
(23.9)\end{array}$ & & $\begin{array}{l}15 \\
(32.6)\end{array}$ & 19 (41.3) & $\begin{array}{l}12 \\
(26.1)\end{array}$ & \\
\hline & $S N N A P^{4}$ & $\begin{array}{l}8 \\
(3.1)\end{array}$ & $\begin{array}{l}169 \\
(65.8)\end{array}$ & $\begin{array}{l}80 \\
(31)\end{array}$ & & $\begin{array}{l}2 \\
(0.8)\end{array}$ & $\begin{array}{l}156 \\
(60.7)\end{array}$ & $\begin{array}{l}99 \\
(38.5)\end{array}$ & & $\begin{array}{l}30 \\
(11.7)\end{array}$ & $\begin{array}{l}134 \\
(52.1)\end{array}$ & $\begin{array}{l}93 \\
(36.2)\end{array}$ & \\
\hline & Tigray & $\begin{array}{l}4 \\
(6.8)\end{array}$ & $33(55.9)$ & $\begin{array}{l}22 \\
(37)\end{array}$ & & $\begin{array}{l}0 \\
(0.0)\end{array}$ & 39 (66.1) & $\begin{array}{l}20 \\
(33.9)\end{array}$ & & $\begin{array}{l}6 \\
(10.2)\end{array}$ & $28(47.5)$ & $\begin{array}{l}25 \\
(42.4)\end{array}$ & \\
\hline Average \% & & $(8.0)$ & (63.0) & (29) & & (1.9) & (63.3) & (34.9) & & $(17.6)$ & $(43.2)$ & (39.2) & \\
\hline
\end{tabular}


*, **, *** Statistically significant at $P<0.05, P<0.01$, and $P<0.001$, respectively (Chi-square analysis); ${ }^{1}$ holding or pursuing; ${ }^{2}$ Healthe workers- nurse, physician, pharmacist, lab assistant, ${ }^{3}$ Benishangul-Gumaz; ${ }^{4}$ Southern Nations, Nationalities and people.

Table 7: Correlation between scores of knowledge, attitude, and practice

\begin{tabular}{|llc|}
\hline Variable & Correlation Coefficient & $p$-value \\
\hline Knowledge-Attitude & $0.162^{* * *}$ & $<0.001$ \\
\hline Attitude-Practice & $0.199 * * *$ & $<0.001$ \\
\hline Knowledge-Practice & 0.037 & 0.154 \\
\hline$* * * * *$ Correlation significant at 0.01, and 0.001 level \\
\hline
\end{tabular}

\section{Discussion}

Around 1.2 billion COVID-19 infections and 3.3 million deaths have been projected for Africa if containment measures fail, nevertheless, stringent adherence to social distancing measures is envisaged to reduce the contact rate and curtail the transmission multifold [30, 31]. The message is clear, Ethiopians must comprehend and sternly abide by the recommendations and handling strategy vis-à-vis the control and prevention of COVID-19. On the precincts of limited scientific information on COVID-19, the WHO had suggested improving knowledge, prevention and control measures in health care and community settings [14]. The novelty of this virus, along with its uncertainties, makes it indispensable for health authorities to plan appropriate stratagems. It is therefore of paramount pertinence that the KAP of the population be studied to guide these efforts. To the best of our knowledge, this is the first study in Ethiopia regarding general public's KAP and assessment of risk of infection towards COVID-19 among Ethiopians, albeit, some studies have been done with limited sample sizes including higher education communities [26], undergraduate students in Debre Berhan University [27], nurses in Northern Ethiopia [28] and visitors in Jimma University Medical Center [29].

In our survey, with respondents, being predominantly male and educated (68\% holding undergraduate degree or higher), we found that the average knowledge score of Ethiopians was moderate at $11.2 \pm 2.2$, with an overall correct-response rating of $74.7 \%$ about COVID-19. This is in lines parallel to the results ( 73.8 $\%)$ observed among undergraduate students from Debre Berhan University [27] and hospital visitors in Jimma University Medical center [29]. The rating ranged widely among demographic variables indicating that some participants had satisfactory knowledge (29\%) about the disease while a poor knowledge score rating was documented for others (8\%). Ethiopians in the age-group of 30-49 recorded higher knowledge scores, plausibly due to a greater access to information intertwined strongly with the implications of higher education. Based on the limited information available to date, the risk of pets spreading the virus that causes COVID-19 in people is considered to be low. At this time, there is no evidence that animals play a significant role in spreading the virus that causes COVID-19 [32] however, $60.9 \%$ answered the other way due to lack of information about the fact. On the other hand, social distancing has been projected as the key to prevent the current pandemic [30,31]. Remarkably, $45.4 \%$ had responded as 2 feet, instead of the recommended 6 feet, which could be bracketed together with the failure of the mass to retrieve correct information. On a surprising note, equipped with the correct information about its genesis in China, 4 in 10 participants wrongly expanded 'COVID-19' as 'China originated Virus disease-2019'. By the same token, those with low education status possibly attributable to restricted access to credible and timely information about the disease in the rural regions. This variation in levels of knowledge may be reflective of the current COVID-19 information landscape in the country. Although the government and health authorities have been consistently disseminating COVID-19 information since the disease was first detected in Ethiopia [33], there has also been a surge in false and inaccurate information [34]. This demands dissemination of correct knowledge in a timely manner to the various strata of the society.

Several surveys, conducted in other countries have indicated differences in levels of COVID-19 knowledge-score and correct response rating among the general population. A similar correct response rating ( 74\%) of the general public of Ethiopia (this study) and undergraduate Ethiopian university students [27] have been documented as against higher values of $84.7 \%$ in Sudan [21] and $80 \%$ in Nigeria [22]. Differences have been observed in the studies conducted in other countries such as Egypt [19], Tanzania [25], Nepal [35], Malaysia [36], and Indonesia [37]. The dissimilarities in the knowledge-appraisal questionnaires do not make it possible for accurate comparisons of knowledge levels across these studies. Moreover, barring Bangladesh and our study, all the previous surveys embraced female participants as the major respondents. Interestingly, knowledge score significantly differed with respect to gender of the respondents in other countries, while such trend was not evident for Ethiopia and Egypt.

In general, Ethiopians (63\%) showed moderate attitude towards the current pandemic in our survey. Notably, 35\% respondents expressed reassuring/good attitude as against a mere $2 \%$, displaying poor attitude towards COVID-19. For instance, 9 out of 10 participants agreed to isolate themselves if symptomatic while three out of four appreciated the disease containment endeavors of the government. By the same token, Aynalam et al., [27] reported that more than 80 $\%$ of the respondents in their study were upbeat about Ethiopia's triumph against the COVID-19 fiasco. At this juncture, drastic measures of the Ethiopian government in mitigating the spread of the virus, including the declaration and enforcement of a SoE for five months, door to door temperature check by health personnel, and closure of education institutes and worship places merit special mention. Our study evinced that a low fraction (11.5\%) of respondents was unconvinced with the government's efforts in fighting against COVID-19. To talk about other African nations, pertinently, $71 \%$ and $60.9 \%$ of Nigerians and Sudanese respectively are buoyant about the win against COVID-19 through their respective governmental actions [22, 23]. Augmented attitude scores bore a direct correspondence with the age and education level in our study. Correlational analysis also augments the findings of present study as knowledge was positively correlated with the attitudes significantly and the same was observed in Indonesia [37]. Nine out of ten were of the view that COVID-19 is posing serious public health threat, owing to its highly contagious nature and global status, however, only 6 out 10 seemed to be panic-stricken. This may be explained in the light of the current observation that Ethiopia is one of the least affected country in the world with a low mortality. However, probability of

Page $10 / 16$ 
asymptomatic individuals and low rate of detection in the country need to be addressed as well. On the other hand, around 3 out of 10 respondents averred the virus to be a potential bioweapon, while, corresponding results were 1 out of 4 in Egypt [19] and nearly 1 out of 2 (50\%) in Nigeria [38]. In the context of the current dearth of scientific evidence, there is enormous heated discussion globally on the synthetic versus natural origin of SARS-CoV-2, responsible for COVID19. Around $22 \%$ of the Ethiopian respondents in our study vouched for its synthetic genesis as against $36 \%$ Nigerians [22].

Needless to state that the possession of adequate knowledge and apt attitude towards the disease may not suffice, the requisite is to employ and engage in appropriate practices to prevent and combat the viral assault. $36.2 \%, 52.4 \%, 56.3 \%$, and $67.6 \%$ of the respondents asserted the use of nose mask, maintenance of social distancing, avoidance of crowded places and regular washing of hands respectively as against a quarter of the participants who continued to resort to the unique Ethiopian style of greeting, involving bodily contact. This was suggestive of a low willingness of the participants to make behavioral changes towards COVID-19 with respect to some of the day to day practices. A number of factors associated for the poor practices, such cost of the mask, sanitizer, and low availability of the protection materials, and culture (greetings, eating together). Another survey in Ethiopia showed $56 \%$ of undergraduate students and $66 \%$ hospital visitors not maintained social distance [27, 29] during March 18-24. During this period 8 out of 10 people not wearing nose mask when leaving home [29], but it has improved to 1 out 5 in this study during May. The similar percentage of people wearing mask was observed in neighboring country of Egypt [19]. Whereas, another African peoples of Tanzanians shows $80 \%$, Sudanese at $49.3 \%$, and Nigerians at $65 \%$ [25, 21, 22]. In case of Chinese study almost all used face masks when they go out during the current pandemic [10], that may be the reason they got succeeded in the disease spread.

Most importantly, a considerable fraction of the participants (17.6\%) seems to be least bothered and consequently non-adherence to these precautionary measures. Specifically, this encompassed females, young aged responders, unmarried, those with lower education status, self-employed and unemployed, and participants with poor knowledge and those hailing from Somali and Afar region. Previous studies in other countries have attested the correspondence of higher risk taking behavior with younger age, low education levels and lifestyle in rural areas [10, 39]. In contrast with our results, Zhong et al., (2020) found a greater correlation of non-recommended/dangerous practices to the male participants in China [10]. On the other hand, lockdown was imposed in many countries for certain number of days. However, no lockdown protocol has been enforced in Ethiopia till the date of drafting this manuscript. Although, the number of confirmed cases and deaths are considerably low in Ethiopia in contrast to rest of African countries, there seems to be a gradual increase in recent weeks (9,503 on $19^{\text {th }}$ July, 2020) [9]. In this regard, less than half of the participants ( $\left.41 \%\right)$ in our survey stood in support of a lockdown in Ethiopia. There was a positive correlation between attitudes and practices while no correlation between knowledge and practices. This might be explained as government strict action on prevention practices and peoples willingness towards the action. While previous studies in other countries found positive correlation between knowledge and practices [10, 40].

With regard to risk of infection, around $18 \%$ people could be bracketed under high risk category, it means around 19.5 million peoples are in high risk in Ethiopia. Considering the limited representation of various sections of the population and the fact that $>95 \%$ of the participants in our survey had college education, the numbers in the high risk category could be plausibly much more in the real scenario. Among gender, we found women's are at high risk than man. In many settings, women and girls are highly vulnerable and at increased risk during an epidemic or crisis, because they are responsible not only for caring for the elderly and children, but because they often make up more than half of the healthcare workforce [41]. Surprisingly, healthcare workers were in higher risk (18.3\%) than the students (14.6\%), even though the former group exhibited adequate/good knowledge (55\%) than the latter counter parts with 26 $\%$ and $20 \%$ knowledge score, respectively. At this juncture, it would be relevant to mention that healthcare workers in Ethiopia had demonstrated an insufficient knowledge and perception but positive attitude during Ebola outbreak in 2015, thereby, vouching for an intense training for the healthcare professionals [42]. These findings clearly evince the significance of improving the various practices of the Ethiopian citizens towards COVID-19 through timely health education and dissemination of correct information in various nook and crannies of the country, which are also envisaged to contribute in improving the attitude, knowledge and perception of the mass towards COVID-19.

\section{Limitation of the study}

The authors had solely relied on their online/social media networks (Telegram, Facebook, WhatsApp and email accounts) for circulation of the survey link. As a result, considerable fraction of the population could not participate in the survey. Moreover, when compared to current population in Ethiopia, the surveysamples were over representative of male respondents, below the age of 50, those with university level education and mostly employed in the public sector. $A$ more systematic, community based, inclusive sampling method with local language is recommended to improve representativeness and generalizability of the findings. The survey questions were generally used and modified based on previously published KAP assessment carried out on COVID-19 in Ethiopia. Despite these limitations, our findings provide valuable information about the KAP of Ethiopians during a peak period of the COVID-19 outbreak.

\section{Conclusion}

As an outcome of this survey, we could gauge a moderate KAP level of the Ethiopians towards COVID-19, an observation of immense pertinence to limit the spread of the disease. However, KAP gap significantly differed among demographic variables except with respect to gender for knowledge level, and gender for attitude level, and gender and occupation for practices. A considerable fraction of respondents indicated a poor practice. Although the government has taken major steps to restrain the spread of the disease, a greater endeavor needs to be channelized to support the demographic variables, projected with high risk of infection (participants with low education status, 18-29 age-group, unemployed responders and those hailing from Somali and Afar region). The results of the study are expected to be expedient for public health policy-makers and health workers. With the objective of improving the practices of the masses towards COVID-19, the government must intensify its health education programs, particularly amidst the high risk category participants. On a concluding note, the authors are anticipative of a concerted endeavor of the Ethiopian government and the public in the battle against COVID-19.

\section{Declarations}


A note of gratitude is extended to all the participants for responding and providing us with valuable online survey information. Heartfelt appreciation is forwarded to Mr. Tibebu D. Mersha, Director, for Information and Communication Technology, Addis Ababa Science and Technology University for assisting in managing Google-form data.

\section{Author Contributions}

Conceptualization: Solomon Benor, Solomon Abera, Ayele Mandefro, Rocktotpal Konwarh, Arumuganainar Suresh.

Data curation: : Solomon Benor, Solomon Abera, Ayele Mandefro, Rocktotpal Konwarh, Arumuganainar Suresh.

Formal analysis: Solomon Benor, Arumuganainar Suresh.

Funding acquisition: Arumuganainar Suresh.

Investigation: Solomon Benor, Solomon Abera, Ayele Mandefro, Rocktotpal Konwarh, Arumuganainar Suresh.

Methodology: Solomon Benor, Solomon Abera, Ayele Mandefro, Rocktotpal Konwarh, Arumuganainar Suresh.

Project administration: Solomon Benor, Arumuganainar Suresh.

Resources: Solomon Benor, Solomon Abera, Ayele Mandefro, Rocktotpal Konwarh, Arumuganainar Suresh.

Software: Arumuganainar Suresh, Rocktotpal Konwarh.

Supervision: Solomon Benor, Arumuganainar Suresh.

Validation: Solomon Benor, Solomon Abera, Ayele Mandefro, Rocktotpal Konwarh, Arumuganainar Suresh.

Visualization: Solomon Benor, Solomon Abera, Ayele Mandefro, Rocktotpal Konwarh, Arumuganainar Suresh.

Writing - original draft: Arumuganainar Suresh. Solomon Benor, Solomon Abera, Ayele Mandefro.

Writing - review \& editing: Solomon Benor, Rocktotpal Konwarh, Arumuganainar Suresh.

\section{Data availability statement}

The datasets generated during and/or analysed during the current study are available from the corresponding author on reasonable request.

\section{Funding}

Though no formal funding was provided, this research was conducted using the resources and research priority directions of the Addis Ababa Science and Technology University.

Competing interests: The authors have declared that no competing interests exist.

\section{References}

1. World Health Organization (WHO) (2020) Statement on the second meeting of the International Health Regulations (2005) Emergency Committee regarding the outbreak of novel coronavirus (2019-nCoV)". In WHO. Retrived January 31, 2020 from https://www.who.int/news-room/detail/30-01-2020statement-on-the-second-meeting-of-the-international-health-regulations-(2005)-emergency-committee-regarding-the-outbreak-of-novel-coronavirus-(2019ncov).

2. WHO (2020) Director-General's opening remarks at the media briefing on COVID-19. In WHO. Retrived March 11, 2020 from: https://www.who.int/dg/speeches/detail/who-director-general-s-opening-remarks-at-the-media-briefing-on-covid-19--11-march-2020.

3. Rabi, F. A., Al Zoubi, M. S., Kasasbeh, G. A., Salameh, D. M., \& Al-Nasser, A. D. (2020). SARS-CoV-2 and coronavirus disease 2019: what we know so far. Pathogens, 9(3), 231.https://doi.org/10.3390/pathogens9030231

4. Wan, Y., Shang, J., Graham, R., Baric, R. S., \& Li, F. (2020). Receptor recognition by the novel coronavirus from Wuhan: an analysis based on decade-long structural studies of SARS coronavirus. Journal of virology, 94(7). https://doi.org/10.1128/jvi.00127-20 
5. Wu, Y. (2020). Compensation of ACE2 function for possible clinical management of 2019-nCoV-induced acute lung injury. Virologica Sinica, 1-3. https://doi.org/10.1007/s12250-020-00205-6

6. Wu, F., Zhao, S., Yu, B., Chen, Y. M., Wang, W., Song, Z. G., ... \& Yuan, M. L. (2020). A new coronavirus associated with human respiratory disease in China. Nature, 579(7798), 265-269. https://doi.org/10.1038/s41586-020-2008-3

7. Jiang, S., Shi, Z., Shu, Y., Song, J., Gao, G. F., Tan, W., \& Guo, D. (2020). A distinct name is needed for the new coronavirus. Lancet (London, England), 395(10228), 949. https://doi.org/10.1016/s0140-6736(20)30419-0

8. Gandhi, M., Yokoe, D. S., \& Havlir, D. V. (2020). Asymptomatic transmission, the Achilles' heel of current strategies to control COVID-19. The New England Journal of Medicine 382:2158-2160. https://doi.org/10.1056/nejme2009758

9. Johns Hopkins University (JHU) (2020) COVID-19 Dashboard by the Center for Systems Science and Engineering (CSSE) at Johns Hopkins University (JHU). Retrived July 29, 2020 from https://coronavirus.jhu.edu/map.html.

10. Zhong, B. L., Luo, W., Li, H. M., Zhang, Q. Q., Liu, X. G., Li, W. T., \& Li, Y. (2020). Knowledge, attitudes, and practices towards COVID-19 among Chinese residents during the rapid rise period of the COVID-19 outbreak: a quick online cross-sectional survey. International Journal of Biological Sciences, 16(10), 1745. https://doi.org/10.7150/ijbs.45221

11. Centers for Disease Control (CDC) and Prevention (2015) About Ebola virus disease. 2015. Retrived July 19, 2020 from http://www.cdc.gov/vhf/ebola/about.html.

12. Konwarh, R. (2020). Nanobodies: Prospects of Expanding the Gamut of Neutralizing Antibodies Against the Novel Coronavirus, SARS-CoV-2. Frontiers in Immunology, 11. https://doi.org/10.3389/fimmu.2020.01531

13. Li, J. Y., You, Z., Wang, Q., Zhou, Z. J., Qiu, Y., Luo, R., \& Ge, X. Y. (2020). The epidemic of 2019-novel-coronavirus (2019-nCoV) pneumonia and insights for emerging infectious diseases in the future. Microbes and infection, 22(2), 80-85. https://doi.org/10.1016/j.micinf.2020.02.002

14. WHO (2020) Rolling Updates on Coronavirus Disease (COVID-19). In WHO. Retrieved July 17, 2020 from https://www.who.int/emergencies/diseases/novel-coronavirus-2019/events-as-they-happen.

15. Johns Hopkins Coronavirus Resource Center (2020) Johns Hopkins Coronavirus Resource Center. 2020. From: https://coronavirus.jhu.edu/

16. Ajilore, K., Atakiti, l., \& Onyenankeya, K. (2017). College students' knowledge, attitudes and adherence to public service announcements on Ebola in Nigeria: Suggestions for improving future Ebola prevention education programmes. Health Education Journal, 76(6), 648-660. https://doi.org/10.1177\%2F0017896917710969

17. Person, B., Sy, F., Holton, K., Govert, B., \& Liang, A. (2004). Fear and stigma: the epidemic within the SARS outbreak. Emerging infectious diseases, 10(2), 358. https://doi.org/10.3201/eid1002.030750

18. ALdowyan, N., Abdallah, A. S., \& El-Gharabawy, R. (2017). Knowledge, Attitude and Practice (KAP) Study about Middle East Respiratory Syndrome Coronavirus (MERS-COV) among Population in Saudi Arabia. International Archives of Medicine, 10. https://www.researchgate.net/deref/http\%3A\%2F\%2Fdx.doi.org\%2F10.3823\%2F2524

19. Abdelhafiz, A. S., Mohammed, Z., Ibrahim, M. E., Ziady, H. H., Alorabi, M., Ayyad, M., \& Sultan, E. A. (2020). Knowledge, perceptions, and attitude of egyptians towards the novel coronavirus disease (COVID-19). Journal of Community Health, 1-10. https://doi.org/10.1007/s10900-020-00827-7

20. Abuya, T., Austrian, K., Isaac, A., Kangwana, B., Mbushi, F., Muluve, E., ... \& Pinchoff, J. (2020). CovID-19-related knowledge, attitudes, and practices in urban slums in Nairobi, Kenya: Study description. From https://knowledgecommons.popcouncil.org/cgi/viewcontent.cgi? article $=1998 \&$ context $=$ departments_sbsr-pgy

21. Mousa, K. N. A. A., Saad, M. M. Y., \& Abdelghafor, M. T. B. (2020). Knowledge, attitudes, and practices surrounding COVID-19 among Sudan citizens during the pandemic: an online cross-sectional study. Sudan Journal of Medical Sciences (SJMS). http://dx.doi.org/10.18502/sjms.v15i5.7176

22. Isah, M. B., Abdulsalam, M., Bello, A., Ibrahim, M. I., Usman, A., Nasir, A., ... \& Shuaibu, A. (2020). Corona Virus Disease 2019 (COVID-19): Knowledge, attitudes, practices (KAP) and misconceptions in the general population of Katsina State, Nigeria. medRxiv. From: https://www.medrxiv.org/content/10.1101/2020.06.11.20127936v2

23. Nicholas, T., Mandaah, F. V., Esemu, S. N., Vanessa, A. B. T., Gilchrist, K. T. D., Vanessa, L. F., \& Shey, N. D. (2020). COVID-19 knowledge, attitudes and practices in a conflict affected area of the South West Region of Cameroon. The Pan African Medical Journal, 35(34). https://doi.org/10.11604/pamj.supp.2020.35.2.22963

24. Serwaa, D., Lamptey, E., Appiah, A. B., Senkyire, E. K., \& Ameyaw, J. K. (2020). Knowledge, risk perception and preparedness towards coronavirus disease2019 (COVID-19) outbreak among Ghanaians: a quick online cross-sectional survey. The Pan African Medical Journal, 35(44). https://doi.org/10.11604/pamj.supp.2020.35.2.22630

25. Byanaku, A., \& Ibrahim, M. (2020). Knowledge, attitudes, and practices (KAP) towards COVID-19: A quick online cross-sectional survey among Tanzanian residents. medRxiv. From https://www.medrxiv.org/content/10.1101/2020.04.26.20080820v2

26. MoSHE (2020) Ministry of Science and Higher Education (MoSHE). Ethiopian National COVID-19 Research Priorities and Alignment. Multi-disciplinary Taskforce Report

27. Aynalem, Y. A., Akalu, T. Y., Gebresellassie, B., Sharew, N. T., \& Shiferaw, W. S. (2020). Assessment of undergraduate student knowledge, practices, and attitude towards COVID-19 in Debre Berhan University, Ethiopia. From https://www.researchsquare.com/article/rs-28556/v1

28. Tadesse, D. B., Gebrewahd, G. T., \& Demoz, G. T. (2020). Knowledge, Attitude, Practice and Psychological response toward COVID-19 among Nurses during the COVID-19 outbreak in Northern Ethiopia. From https://www.researchsquare.com/article/rs-26236/v1

29. Kebede, Y., Yitayih, Y., Birhanu, Z., Mekonen, S., \& Ambelu, A. (2020). Knowledge, perceptions and preventive practices towards COVID-19 early in the outbreak among Jimma university medical center visitors, Southwest Ethiopia. PloS one, 15(5), e0233744. https://doi.org/10.1371/journal.pone.0233744

Page 13/16 
30. United Nations Economic Commission for Africa (UNECA) (2020) COVID-19 in Africa: Protecting Lives and Economies by the Economic Commission for Africa. From https://www.uneca.org/sites/default/files/PublicationFiles/eca_covid_report_en_rev16april_5web.pdf

31. Lewnard, J. A., \& Lo, N. C. (2020). Scientific and ethical basis for social-distancing interventions against COVID-19. The Lancet. Infectious diseases, 20(6), 631. https://doi.org/10.1016/s1473-3099(20)30190-0

32. Food and Drug Administration (FDA) (2020) Helpful Questions and Answers about Coronavirus (COVID-19) and Your Pets. Retrieved July 17, 2020 from https://www.fda.gov/consumers/consumer-updates/helpful-questions-and-answers-about-coronavirus-covid-19-and-your-pets.

33. UNICEF (2020) Creating awareness about COVID-19 in Ethiopia, PDF. From https://www.unicef.org/ethiopia/media/2706/file

34. Committee to Protect Journalists (CPI) (2020) "Ethiopian journalist Yayesew Shimelis detained following COVID-19 report". Committee to Protect Journalists. 1 April 2020. From https://cpj.org/2020/04/ethiopian-journalist-yayesew-shimelis-detained-fol/

35. Singh, D. R., Sunuwar, D. R., Karki, K., Ghimire, S., \& Shrestha, N. (2020). Knowledge and Perception Towards Universal Safety Precautions During Early Phase of the COVID-19 Outbreak in Nepal. Journal of community health, 1. https://doi.org/10.1007/s10900-020-00839-3

36. Azlan, A. A., Hamzah, M. R., Sern, T. J., Ayub, S. H., \& Mohamad, E. (2020). Public knowledge, attitudes and practices towards COVID-19: A cross-sectional study in Malaysia. Plos one, 15(5), e0233668. https://doi.org/10.1371/journal.pone.0233668

37. Sari, D. K., Amelia, R., Dharmajaya, R., Sari, L. M., \& Fitri, N. K. (2020). Positive Correlation Between General Public Knowledge and Attitudes Regarding COVID-19 Outbreak 1 Month After First Cases Reported in Indonesia. Journal of community health, 1-8. https://doi.org/10.1007/s10900-020-00866-0

38. Olapegba, P. O., Ayandele, O., Kolawole, S. O., Oguntayo, R., Gandi, J. C., Dangiwa, A. L., ... \& lorfa, S. K. (2020). A Preliminary Assessment of Novel Coronavirus (COVID-19) Knowledge and Perceptions in Nigeria. From: https://www.medrxiv.org/content/10.1101/2020.04.11.20061408v2

39. Pawlowski, B., Atwal, R., \& Dunbar, R. I. M. (2008). Sex differences in everyday risk-taking behavior in humans. Evolutionary Psychology, 6(1), 147470490800600104. https://psycnet.apa.org/doi/10.1177/147470490800600104

40. Saqlain, M., Munir, M. M., ur Rehman, S., Gulzar, A., Naz, S., Ahmed, Z., ... \& Mashhood, M. (2020). Knowledge, attitude, practice and perceived barriers among healthcare professionals regarding COVID-19: A Cross-sectional survey from Pakistan. Journal of Hospital Infection. https://doi.org/10.1016/j.jhin.2020.05.007

41. Wenham, C., Smith, J., \& Morgan, R. (2020). COVID-19: the gendered impacts of the outbreak. The Lancet, 395(10227), 846-848. https://doi.org/10.1016/S0140-6736(20)30526-2

42. Abebe, T. B., Bhagavathula, A. S., Tefera, Y. G., Ahmad, A., Khan, M. U., Belachew, S. A., ... \& Abegaz, T. M. (2016). Healthcare professionals' awareness, knowledge, attitudes, perceptions and beliefs about Ebola at Gondar University Hospital, Northwest Ethiopia: a cross-sectional study. Journal of Public Health in Africa, 7(2). https://doi.org/10.4081/jphia.2016.570

\section{Figures}




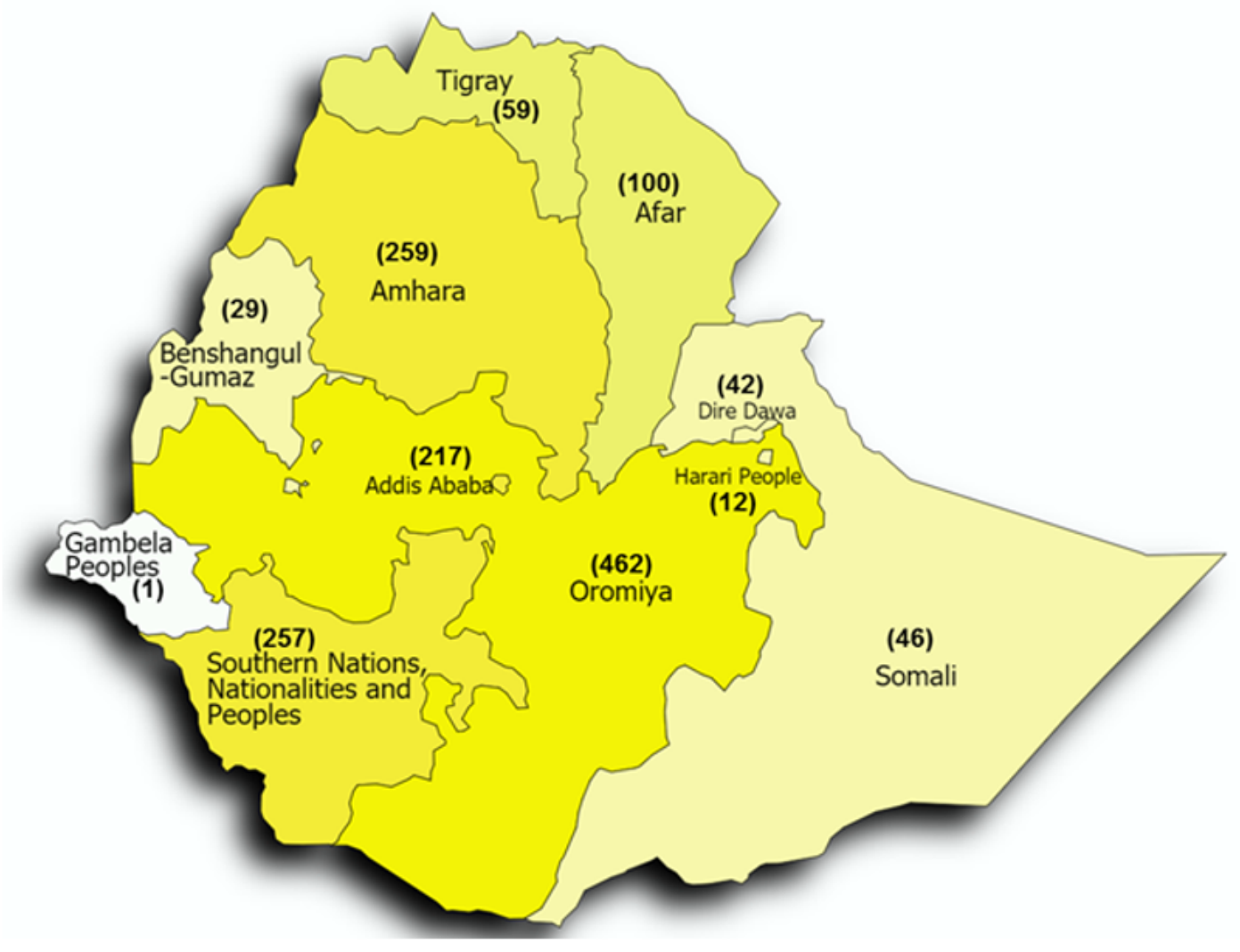

Figure 1

Distribution of KAP survey sample $(n=1,484)$ towards COVID-19 across various states of Ethiopia 


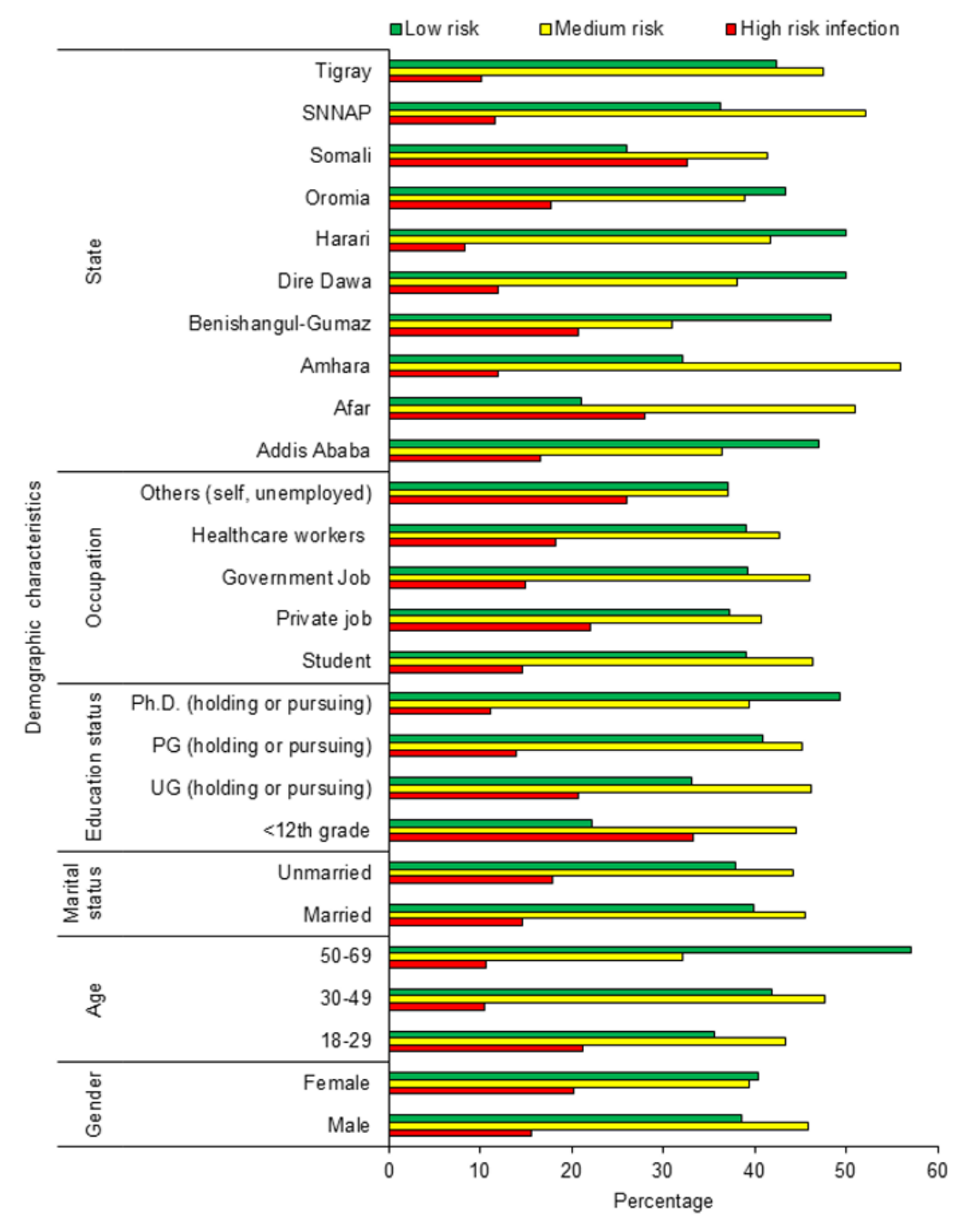

Figure 2

Risk of infection of COVID-19 among demographic variables of Ethiopians $(n=1,484)$

\section{Supplementary Files}

This is a list of supplementary files associated with this preprint. Click to download.

- S1Table.docx

- S1Fig.tif 